\title{
MEMORIA DA ENFERMAGEM BRASILEIRA
}

\author{
Maria Angela Lagrange M. Reis*
}

RBEn/01

REIS, M.A.L.M. — Memória da enfermagem brasileira. Rev. Bras. Enf.; DF, 30 : 73-75, 1977.

A História, embora nem sempre assim considerada, é a base do presente, imprescindivel ao futuro. Pedro CALMON 1, numa conferência proferida no VI Curso de Estudo de Problemas Brasileiros, realizado no Forum de Ciência e Cultura da UFRJ, frisou a importância da conservação de valores de um povo. "Um povo sem raízes é um povo alienado", comentou o ilustre conferencista, lamentando o estado em que se encontram nossos arquivos públicos apresentandose sem funcionários com formação adequada ou com poucos arquivologistas, e sem condições materiais para tratarem do material sob sua guarda. As informaçōes contidas em arquivos públicos ou particulares são dificilmente recuperadas por pesquisadores históricos após longa busca, muitas vezes resultando em uma pesquisa infrutifera. Outro historiador, COMMAGER 2, comenta que "um povo sem história, ou ignorante de sua História, é a mesma coisa que um homem sem memória - condenado para sempre a fazer as mesmas descobertas já conhecidas no passado, a inventar as mesmas técnicas, a lutar com os mesmos problemas, a cometer os mesmos erros; con- denado, também, a privar-se dos prazeres da reminiscência".

Fatos históricos relevantes concernentes à nossa cultura em geral ou a aspeetos especializados dessa cultura - ciência e tecnologia, por exemplo - são em muitas ocasiōes encontrados em fontes não convencionais como cartas, manuscritos diversos, fotografias e medalhas comemorativas. Livros que se tornam raros por terem suas ediçōes esgotadas ou por terem sido editados no exterior abrigam dados de dificil alcance para o interessado. Todos esses informes, podendo ser analisados por um especialista, talvez permitissem a decifração de acontecimentos influenciadores de determinadas ocorrências, sem nexo até então. Até há poucos anos tratava-se de fontes desconsideradas em geral, ou melhor, não sendo registradas, catalogadas, classificadas e recuperadas.

Ultimamente, muitos desses dados sobre nossa História em geral ou sobre alguns de seus ângulos têm sido guardados em arquivos denominados "memórias", verdadeiros depositários de informaçōes contidas em formas micrográficas, "tapes", "slides" e também numas

" Professora de "Pesquisa Bibliográfica" da Escola de Enfermagem Ana Néri da UFRJ. 
poucas publicações, em fotografias, etc. A "moda" de "memórias" tem a sua razão de ser. O homem, quanto mais se desenvolve técnica e científicamente, mais percebe a necessidade de conhecer suas raízes, ter a base sobre a qual irá sedimentando novos conhecimentos, descobertas e experiências que serão assim mais familiares a seus sucessores.

As "memórias" costumam ser constituidas de materiais pertencentes a particulares que permitem sua reproduçāo, às vezes mediante algumas cláusulas, de depoimentos gravados por entrevistadores especialistas em história oral ("depoimentos gravados de acordo com técnicas estabelecidas por especialistas"), de microfilmes e microfichas, enfim, geralmente de fontes não convencionais. A característica principal das "memórias" é a escolha criteriosa do conteúdo, avaliação do material arquivado, tratamento adequado do mesmo permitindo pronta recuperação. Não se trata portanto de mais um acúmulo de papéis, reunido indiscriminadamente. As informaçōes são colecionadas e organizadas, sendo separadas conforme os objetivos das "memórias". Existe uma catalogação e classificação dos dados considerados, evitandose assim um conjunto caótico de informaçōes irrelevantes e irrecuperáveis. Por outro lado, a perda progressiva de tempo para pesquisas faz com que o pesquisador necessite ter todas as informaçōes a seu alcance, no momento que delas tiver necessidade. As "memórias" visam principalmente a conservação de informaçōes contidas em fontes não convencionais que, de outra maneira estariam perdidas.

A enfermagem no Brasil tem todo um passado de lutas, vitórias, esforço pessoal e coletivo, participação de especialistas de outras áreas, colaboração de enfermeiras e entidades estrangeiras. Passado esse mui digno de ser carinhosamente conservado como exemplo, recordação e experiência. Fol o embasamento da profissāo tal como ela se apresenta hoje em nosso país, agora em nível su- perior, cada vez mais se firmando no conceito dos brasileiros, prestando relevantes serviços à comunidade. Todo este complexo, apesar de não muito longínquo, tende a se esvair, desaparecendo e sofrendo um processo de desgaste devido ao próprio tempo, inimigo implacável de memórias e amigo de fantasias, à deterioração de materiais bibliográficos históricos e que não tiveram novas edições de seus exemplares, à dispersão de materiais diversos.

A tradição oral muito tem ajudado para a existência de uma certa preservaçāo mas, muitas das "contadoras" de fatos históricos relativos à enfermagem vêm a falecer sem que tenham escrito ou gravado seus depoimentos, perdendo-se assim mais uma fonte rica de fatos históricos.

Se a Enfermagem no Brasil for iniciada praticamente a partir de Ana Néri, são cerca de cento e cinqüenta anos a serem atualizados, conservados e catalogados, pouco tempo em relação à história, possíveis ainda de serem recuperados através de pesquisas diversas. Muitas enfermeiras ou familiares de enfermeiras conservam documentos importantes, não os doando com receio de que venham a se dispersar no conglomerado de publicaçōes existentes em nossas bibliotecas. Escolas de Enfermagem guardam arquivos ricos em informaçōes especializadas no assunto; a Escola de Enfermagem Ana Néri, pioneira do ensino da enfermagem no Brasil, cuida particularmente desses documentos de valor inestimável. Em hospitais também há informações relevantes a serem consideradas e tratadas adequadamente. Tantos dados existentes em estado latente - tendendo a se dispersarem, se perderem no tempo!

Assim como os povos e as culturas, também a enfermagem brasileira tem necessidade de ter suas raízes fixadas. suas tradições escritas, os depoimentos de grandes enfermeiras e de pessoas ligadas à enfermagem gravados de forma técnicamente perfeita. 
Eis porque este artigo lança a idéia da "Memória da Enfermagem Brasileira". Que aconteçam de acordo com todos os requisitos necessários - local e recursos adequados - permitindo assim à Enfermagem Brasileira não sofrer os danos de "um povo sem história".

\section{REFERENCIAS}

1 - CALMon, Pedro. Conferência proferida no VI Curso de Estudo de Problemas Brasileiros. Rio de Janeiro, FCC/UFRJ, 1976. Tape.
Não cabe neste artigo a citação de detalhes técnicos relativos à instalação, funcionamento e movimentação desse arquivo. Por ora, apenas a semente é plantada. Dependerá da Enfermagem Brasileira fazer com que se transforme numa frondosa e segura árvore.

\section{BIBLIOGRAFICAS}

2 - COMMAGER, Henry Steele. Iniciaçāo ao estudo da historia. (The nature and study of history). Trad. Waltensir Dutra. Rio de Janeiro, Zahar eds. /1967/ $207 \mathrm{p}$. 